\title{
Health-benefitting Biologically Active Substances in Edible Apricot Flowers
}

\author{
Martina Göttingerová \\ Department of Fruit Science, Faculty of Horticulture in Lednice, Mendel \\ University in Brno, Valtická 337, 69144 Lednice, Czech Republic
}

Michal Kumšta

Department of Viticulture and Enology, Faculty of Horticulture in Lednice, Mendel University in Brno, Valtická 337, 69144 Lednice, Czech Republic

\section{Tomáš Nečas \\ Department of Fruit Science, Faculty of Horticulture in Lednice, Mendel University in Brno, Valtická 337, 69144 Lednice, Czech Republic}

Additional index words. amygdalin, anthocyanin content, antioxidant capacity, carotenoids, flavonoids, phenolic content, vitamin C

\begin{abstract}
The nutritive quality of food and the aesthetic aspect contribute to the appearance of consumed food. In this study, apricot (Prunus armeniaca L.) flowers were used to determine vitamin $C$, total phenolic content, flavonoids, antioxidant capacity, carotenoids, anthocyanins, and amygdalin. Vitamin $C$ content fluctuated between 24.97 and $47.35 \mathrm{mg} \cdot 100 \mathrm{~g}^{-1}$ fresh weight $(\mathrm{FW})$. The results show that all apricot flowers are a good source of phenolic compounds [404.08-768.45 mg gallic acid equivalent (GAE)/100 g FW] and flavonoids [198.76-538.11 mg catechin equivalent (CE)/100 $\mathrm{g} \mathrm{FW],} \mathrm{and} \mathrm{have}$ good antioxidant capacity [414.66-1026.18 mg Trolox equivalent (TE)/100 g FW]. A high value of anthocyanins was measured in 'Vestar' (28.41 $\left.\mathrm{mg} \cdot 100 \mathrm{~g}^{-1} \mathrm{FW}\right)$ and also in 'Blenheim' (13.40 mg.100 $\left.\mathrm{g}^{-1} \mathrm{FW}\right)$. On the contrary, a low value was found in 'Scout' $\left(1.60 \mathrm{mg} \cdot 100 \mathrm{~g}^{-1} \mathrm{FW}\right)$. The highest value of carotenoids was measured in 'Blenheim' (6.41 mg.100 $\mathrm{g}^{-1} \mathrm{FW}$ ), and the lowest in 'Chuang Zhi Hong' (1.36 mg.100 $\mathrm{g}^{-1} \mathrm{FW}$ ). Amygdalin content fluctuated between 110.81 and $419.78 \mathrm{mg} \cdot 100 \mathrm{~g}^{-1} \mathrm{FW}$. Newly acquired information about the composition and nutritional value of edible flowers give reasons for their consumption.
\end{abstract}

Earth is a plant-oriented planet and horticulture plants have special importance. Horticulture plants add value to Earth's diversity and are fundamental to all life. Fruit, leaves, stems, roots, flowers, and seeds of horticulture plants include high contents of nonnutritive, nutritive, and bioactive compounds such as flavonoids, phenolics, and anthocyanins, as well as nutritive compounds such as sugars, essential oils, carotenoids, vitamins, and minerals, which are used by humans (Güney et al., 2019; Rop et al., 2012; Senica et al., 2019; Zia-Ul-Haq et al., 2014). For centuries, edible flowers have been an integral part of the human diet and have been

Received for publication 25 Mar. 2020. Accepted for publication 17 June 2020.

Published online 17 July 2020.

The results were obtained with the support of project NAZV/ QK1910137 and the plant material was provided through activity no. 6.2.10 ref. 51834/2017-MZE-17253, subprogram "National Program of Conservation and Utilization of Plant Genetic Resources and Agrobiodiversity," which are funded by the Ministry of Agriculture of the Czech Republic.

T.N. is the corresponding author. E-mail: tomas. necas@mendelu.cz.

This is an open access article distributed under the CC BY-NC-ND license (https://creativecommons. org/licenses/by-nc-nd/4.0/). described in detail in ancient literature (He et al., 2015; Lu et al., 2015). They were often used in human medicine and to decorate meals cooked for the higher classes (Rop et al., 2012; Yang and Walters, 1992). Currently, the interest in the availability of fresh edible flowers as part of a diet is growing worldwide (Pires et al., 2019).

There are several reasons why an interest in edible flowers continues to rise. Globalization has contributed not only to increased consumer awareness (rising numbers of edible flower cookbooks, culinary magazines, etc.), but also to a return to the lifestyle of the past, in which edible flowers played an important role. New food processing technologies and rapid distribution of refrigerated and well-preserved foods have also allowed us to revert to previous common and widespread sources of food. Edible flowers are now used to decorate meals and are usually eaten fresh. However, they can also be consumed when dried, in cocktails (frozen in ice cubes), candied, preserved in spirits, etc. (Roberts, 2000). The main sources of edible flowers are vegetables and fruit-bearing medicinal and ornamental plants (Kelley et al., 2001).

The main criteria for assessing the quality of edible flowers are their sensory properties; i.e., their attractiveness, size, shape, color, and (most importantly) their flavor and aroma (Kelley et al., 2002). The color of flowers is predetermined by many chemical compounds; however, the most important issue is the content of carotenoids and flavonoids (Friedman et al., 2010). The presence of these and other phenolic substances in flowers make them a good source of antioxidant capacity (Mato et al., 2000).

The flowers are usually nontoxic, yet one must consider that the daily limit for consumption of the flowers of ornamental plants has not yet been established (Mlček and Rop, 2011). It is known that some flowers contain toxic substances, which make them unsuitable for human diets (Navarro-González et al., 2015). Species from the Rosaceae family, particularly apricots and almonds, are well known for their amygdalin content, a high-risk component in their plant parts (Donald, 2009). Metabolic degradation of amygdalin causes poisonous hydrogen cyanide to be released (Bolarinwa et al., 2014). Knowing that the acute lethal dose of hydrogen cyanide for mammals is $0.5 \mathrm{mg} \cdot \mathrm{kg}^{-1}$ of body weight, the consumption of 50 bitter almonds is deadly for adults; for young children, the fatal amount can be as low as 5 to 10 almonds (World Health Organization, 2012).

The color scale of specific apricot cultivar flowers ranges from white through light pink to pink. The flavor is slightly sour, aromatic, and bitter, typical of all stone fruit. Up to now, no research has focused on analyzing the biologically active substances in apricot flowers. Therefore, the goal of our study was to determine the content of vitamin $\mathrm{C}$, antioxidant capacity, and flavonoid and total phenolic content, and establish the content of carotenoids and anthocyanins in the apricot flowers. Our study was also expanded by examining the content of amygdalin.

\section{Materials and Methods}

Site and plant material. The flowers were harvested from trees gown in the gene pool collection of apricots at the Faculty of Horticulture in Lednice. The site is located in the municipality of Lednice in the south Moravian region in the Czech Republic, at an elevation of $176 \mathrm{~m}$ above sea level, in a location with an average annual temperature of $9.7^{\circ} \mathrm{C}$. The gene pool collection of apricots was planted between 1998 and 1999, with the trees spaced $5 \mathrm{~m}$ between rows and $3 \mathrm{~m}$ within the rows, with grass growing between the rows. The trees were grown as free-growing dwarf trees without a leader, grafted on apricot seedling rootstock. From each cultivar, five trees were planted. Supplemental irrigation has been maintained using a drip system since 2018 .

In total, 15 apricot cultivars with variously colored flowers (Fig. 1) were analyzed. The samples were collected on three dates in 2019 , as the trees gradually flowered. On 25 Mar., samples were collected from the cultivars Chuang Zhi Hong, Goldrich, Bobcot, Kech-pshar, Stark Early Orange, Orangered, Vestar, Scout, and Klosterneuburger. Other samples were collected 2 d later (27 Mar.) 


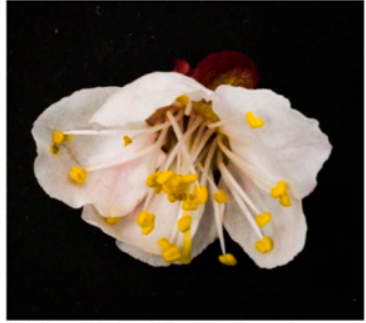

'Blenheim'

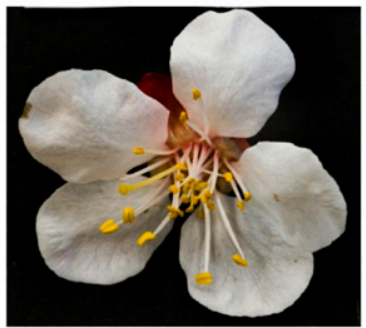

'Gvardějskij'

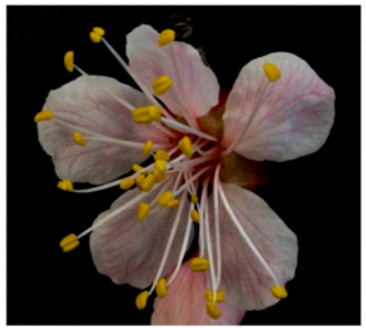

'Kech-pshar'

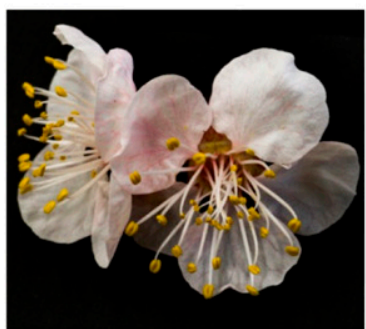

'Orangered'

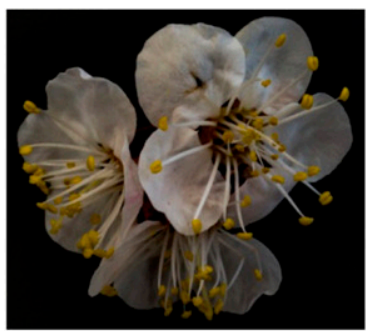

'Stella'

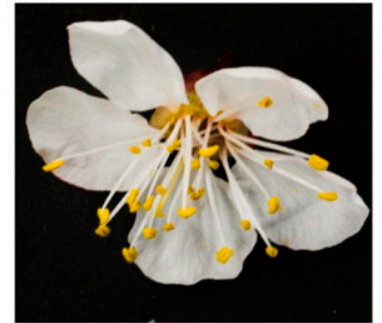

'Bobcot'

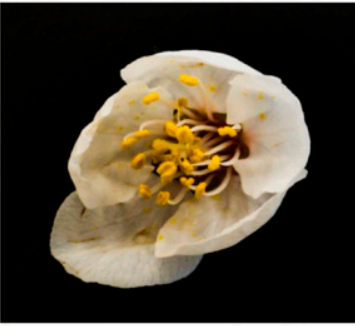

'Harlayne'

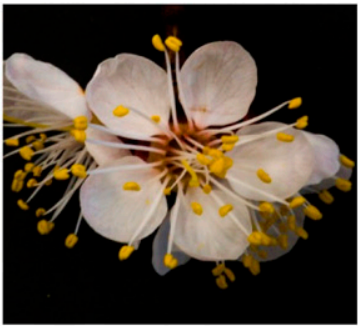

'Klosterneuburger'

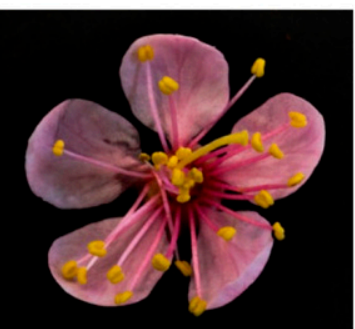

'Scout'

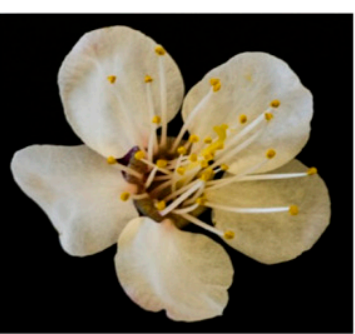

'Velkopavlovická'

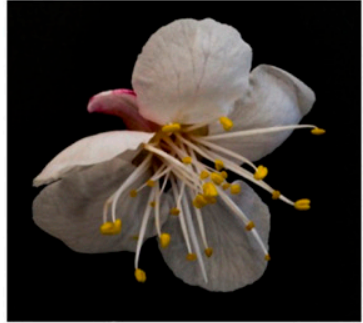

'Goldrich'

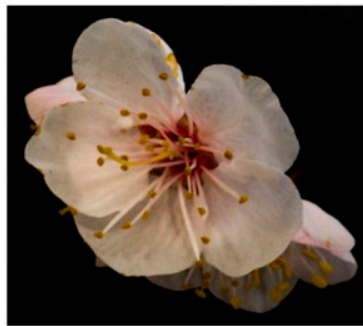

'Chuang Zhi Hong'

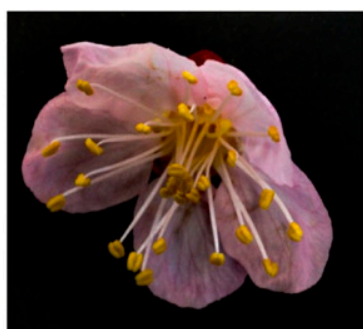

'Marena'

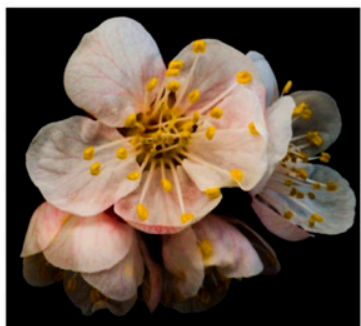

'Stark Early Orange'

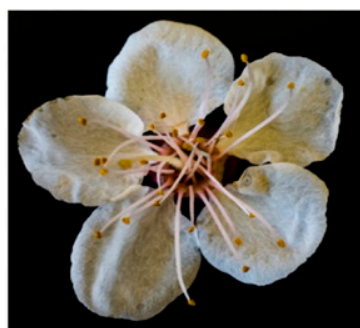

'Vestar'

Fig. 1. The overall appearance of the flowers for the cultivars used in this study.

from the cultivars Harlayne, Velkopavlovická, Blenheim, Gvardějskij, and Marena, and on 1 Apr. from the cultivar Stella. The flowers were harvested as soon as the tree was fully in bloom, always in the morning. From each tree of a cultivar (which was represented by five trees), 50 flowers were taken from the same part of the crown. One sample consisted of mixing 50 flowers from five trees, resulting in a total of 250 flowers. All trees were of comparable age.

Analysis of the plant sample. Chemical analyses of fresh material were carried out immediately after harvesting. To determine the carotenoid content, the flowers were dried in a heat chamber (Sterimat Celpap, Prague, $\mathrm{CZ}$ ) at $50{ }^{\circ} \mathrm{C}$ for $24 \mathrm{~h}$. Each parameter was measured three times for each sample.
Preparation of the plant samples for analyzing total phenolic content, total flavonoids, total antioxidant capacity, and amygdalin. The content of secondary metabolites (phenolic compounds, flavonoids, antioxidant capacity, and amygdalin) was determined from a methanol extract of fresh flower material. Five grams of the sample was homogenized with a hand 
Table 1. Values of qualitative indicators in apricot flowers of the examined varieties.

\begin{tabular}{|c|c|c|c|c|c|c|c|c|c|c|c|c|c|c|c|}
\hline \multirow[b]{2}{*}{ Cultivar } & \multirow[b]{2}{*}{ Flower color } & \multicolumn{2}{|c|}{$\begin{array}{l}\text { Antioxidant capacity } \\
(\mathrm{mg} \mathrm{TE} / 100 \mathrm{~g})\end{array}$} & \multicolumn{2}{|c|}{$\begin{array}{c}\text { Ascorbic acid } \\
\left(\mathrm{mg} \cdot 100 \mathrm{~g}^{-1}\right)\end{array}$} & \multicolumn{2}{|c|}{$\begin{array}{l}\text { Total phenolic content } \\
(\mathrm{mg} \text { GAE } / 100 \mathrm{~g})\end{array}$} & \multicolumn{2}{|c|}{$\begin{array}{c}\text { Flavonoids } \\
(\mathrm{mg} \mathrm{CE} / 100 \mathrm{~g})\end{array}$} & \multicolumn{2}{|c|}{$\begin{array}{l}\text { Anthocyanins } \\
\left(\mathrm{mg} \cdot 100 \mathrm{~g}^{-1}\right)\end{array}$} & \multicolumn{2}{|c|}{$\begin{array}{l}\text { Carotenoids } \\
\left(\mathrm{mg} \cdot 100 \mathrm{~g}^{-1}\right)\end{array}$} & \multicolumn{2}{|c|}{$\begin{array}{l}\text { Amygdalin } \\
\left(\mathrm{mg} \cdot 100 \mathrm{~g}^{-1}\right)\end{array}$} \\
\hline & & Avg & SD & $\overline{A v g}$ & $\mathrm{SD}$ & Avg & SD & Avg & SD & Avg & SD & $\overline{A v g}$ & SD & Avg & SD \\
\hline Blenheim & White & 861.73 & - & 47.35 & $0.27 \mathrm{j}^{\mathrm{z}}$ & 683.01 & 0.141 & 457.30 & 0.121 & 13.40 & $0.13 \mathrm{~h}$ & 6.41 & $0.041 \mathrm{i}$ & 250.05 & $6.14 \mathrm{e}$ \\
\hline Bobcot & White & 414.66 & - & 33.04 & $0.10 \mathrm{c}$ & 404.08 & $0.28 \mathrm{a}$ & 198.76 & $0.06 \mathrm{a}$ & 7.17 & $0.01 \mathrm{e}$ & 1.53 & $0.001 \mathrm{~b}$ & 110.81 & $3.56 \mathrm{a}$ \\
\hline Goldrich & White & 442.70 & - & 24.97 & $0.11 \mathrm{a}$ & 430.82 & $0.20 \mathrm{~b}$ & 230.69 & $0.08 \mathrm{~b}$ & 3.38 & $0.09 \mathrm{~b}$ & 1.46 & $0.002 \mathrm{ab}$ & 137.00 & $0.91 \mathrm{~b}$ \\
\hline Gvardějskij & White & 850.68 & - & 40.15 & $0.25 \mathrm{~g}$ & 712.74 & $1.86 \mathrm{n}$ & 453.33 & $0.22 \mathrm{k}$ & 8.10 & 0.48 ef & 1.74 & $0.003 \mathrm{c}$ & 342.12 & $7.27 \mathrm{~g}$ \\
\hline Harlayne & White & 701.20 & - & 43.42 & $0.37 \mathrm{~h}$ & 549.14 & $0.07 \mathrm{e}$ & 364.74 & $0.08 \mathrm{e}$ & 7.25 & $0.05 \mathrm{e}$ & 3.74 & $0.038 \mathrm{~h}$ & 315.55 & $5.33 \mathrm{f}$ \\
\hline Chuang Zhi Hong & Light pink & 585.63 & - & 29.77 & $0.05 \mathrm{~b}$ & 586.76 & $0.07 \mathrm{~h}$ & 366.30 & $0.10 \mathrm{f}$ & 5.55 & $0.03 \mathrm{~d}$ & 1.36 & $0.003 \mathrm{a}$ & 419.78 & $5.83 \mathrm{~h}$ \\
\hline Kech-pshar & Light pink & 865.87 & - & 43.41 & $0.31 \mathrm{~h}$ & 672.78 & $0.24 \mathrm{k}$ & 478.84 & $0.15 \mathrm{~m}$ & 7.96 & $0.06 \mathrm{ef}$ & 1.96 & $0.003 \mathrm{~d}$ & 136.24 & $2.11 \mathrm{~b}$ \\
\hline Klosterneuburger & White & 750.79 & - & 35.98 & $0.27 \mathrm{~d}$ & 593.15 & $0.15 \mathrm{i}$ & 398.58 & $0.04 \mathrm{i}$ & 5.38 & $0.10 \mathrm{e}$ & 2.60 & $0.008 \mathrm{~g}$ & 160.37 & $4.12 \mathrm{c}$ \\
\hline Marena & Pink & 747.26 & - & 45.83 & $0.16 \mathrm{i}$ & 697.07 & $3.03 \mathrm{~m}$ & 523.77 & $0.16 \mathrm{n}$ & 4.88 & $0.01 \mathrm{~cd}$ & 3.92 & $0.028 \mathrm{i}$ & 200.80 & $2.07 \mathrm{~d}$ \\
\hline Orangered & White & 548.29 & - & 35.97 & $0.28 \mathrm{~d}$ & 513.43 & $0.18 \mathrm{c}$ & 252.83 & $0.19 \mathrm{c}$ & 3.95 & $0.49 \mathrm{bc}$ & 2.15 & $0.052 \mathrm{e}$ & 200.22 & $3.37 \mathrm{~d}$ \\
\hline Scout & Pink & 739.54 & - & 37.52 & $0.18 \mathrm{ef}$ & 649.17 & $0.70 \mathrm{j}$ & 427.44 & $0.10 \mathrm{j}$ & 1.60 & $0.08 \mathrm{a}$ & 1.81 & $0.003 \mathrm{c}$ & 217.43 & $4.96 \mathrm{~d}$ \\
\hline Seo & White & 521.19 & - & 37.78 & $0.14 \mathrm{f}$ & 528.03 & $0.51 \mathrm{~d}$ & 258.17 & $0.10 \mathrm{~d}$ & 8.38 & $0.04 \mathrm{fg}$ & 2.47 & $0.001 \mathrm{f}$ & 322.51 & $3.78 \mathrm{fg}$ \\
\hline Stella & White & 1026.18 & - & 36.34 & $0.11 \mathrm{de}$ & 768.45 & $0.25 \mathrm{o}$ & 538.11 & $0.04 \mathrm{o}$ & 5.50 & $0.26 \mathrm{~d}$ & 1.83 & $0.023 \mathrm{c}$ & 217.76 & $5.40 \mathrm{~d}$ \\
\hline Velkopavlovická & White & 721.53 & - & 37.36 & 0.42 ef & 580.79 & $0.11 \mathrm{~g}$ & 379.83 & $1.01 \mathrm{~h}$ & 9.31 & $0.04 \mathrm{~g}$ & 2.43 & $0.001 \mathrm{f}$ & 211.76 & $3.65 \mathrm{~d}$ \\
\hline Vestar & White & 659.65 & - & 44.80 & $0.37 \mathrm{i}$ & 567.95 & $0.24 \mathrm{f}$ & 376.81 & $0.10 \mathrm{~g}$ & 28.41 & $0.07 \mathrm{i}$ & 2.16 & $0.003 \mathrm{e}$ & 166.90 & $0.75 \mathrm{c}$ \\
\hline
\end{tabular}

${ }^{\mathrm{z}}$ Any two means within a row not followed by the same letter are significantly different at $P \leq 0.05$.

$\mathrm{TE}=$ Trolox equivalent; $\mathrm{GAE}=$ gallic acid equivalent; $\mathrm{CE}=$ catechin equivalent.

blender in $25 \mathrm{~mL} \mathrm{75 \%} \mathrm{methanol.} \mathrm{This} \mathrm{extract}$ was left to stand for $24 \mathrm{~h}$ and was then filtered through filter paper into a 50 -mL measuring flask, to which $75 \%$ methanol was added up to the required volume. Samples were then placed into a $20-\mathrm{mL}$ plastic bottle and frozen until the analysis (Zbíral, 2005).

Total phenolic content, total flavonoids, and total antioxidant capacity. Analyses of all parameters were performed according to the methods of Zloch et al. (2004) by using a Specord 50 Plus spectrophotometer (Analytik, Jena, DE). Total phenolic content was determined after reaction of sample extracts with Folin-Ciocalteu reagent at a wavelength of $765 \mathrm{~nm}$. Total phenolic content was expressed in milligrams GAE per $100 \mathrm{~g} \mathrm{FW}$.

Total flavonoid content was determined by using aluminum chloride and sodium nitrite. The results were expressed in milligrams CE per $100 \mathrm{~g} \mathrm{FW}$.

The 2.2-diphenyl-1-picrylhydrazyl (DPPH) method was used to determine total antioxidant capacity. This method is based on the decolorizing property of the hydrogen radical of DPPH with hydrogen donors, including phenolic compounds. Trolox (6-hydroxy-2.5.7.8-tetramethylchroman-2carboxylic acid) was used as a standard, and the total antioxidant capacity was measured at $515 \mathrm{~nm}$ and then expressed in milligrams TE per $100 \mathrm{~g}$ FW.

Determination of amygdalin content. The method for determining the content of amygdalin used reversed-phase chromatography, as described by Bolarinwa et al. (2014). Before analysis, the extract was centrifuged to remove the remaining solid particles, and the clear extract was diluted further with 0.1 $\mathrm{mol} \cdot \mathrm{L}^{-1}$ perchloric acid solution in a ratio of 1:20 (extract:acid). The diluted extract was subjected to high-performance liquid chromatography (HPLC) analysis in an LC-10A (Shimadzu, Tokyo, JP). Samples were run in a column (Kinetex $2.6 \mu \mathrm{m}$ Polar C18, $100 \times$ $3 \mathrm{~mm}$; Phenomenex, Torrance, CA) and, as a mobile phase, $15 \mathrm{~mm}$ perchloric acid solution was used. The detection was performed at 190 to $320 \mathrm{~nm}$. Amygdalin content was determined according to the calibration curve of the standard at $212 \mathrm{~nm}$ and is expressed in milligrams per $100 \mathrm{~g} \mathrm{FW}$.

Determination of L-ascorbic acid. The concentration of L-ascorbic acid (vitamin C) was determined using HPLC according to the method of Sawant et al. (2010). For the purpose of analysis, $20 \mathrm{~g}$ of flower material was homogenized with a hand blender in 25 $\mathrm{mL}$ of a $0.1-\mathrm{mol} \cdot \mathrm{L}^{-1}$ solution of oxalic acid. The sample was then filtered through gauze into a $100-\mathrm{mL}$ measuring flask, and oxalic acid was added to get the required volume. Twenty milliliters of this solution was centrifuged in EBA 12 (Hettich, Vlotho, DE) for $10 \mathrm{~min}$ at $3500 \mathrm{rpm}$. The supernatant was filtered through a $0.45-\mu \mathrm{m}$ microfilter before injection into the ECB 2000 chromatograph (Ecom, České Meziříčí, CZ). Samples were run in an analytical column (Pack ODS-AQ S-5 $\mu \mathrm{m}, 12 \mathrm{~nm}, 150 \times 4.6 \mathrm{~mm}$; YMC, Shimogyo-ku, JP) and, as a mobile phase, tetrabutylammonium hydroxide with oxalic acid and water at a ratio of 10:20:70 was used. The detection was performed at $254 \mathrm{~nm}$ and the qualitative assessment was carried out on the basis of retention data. The quantitative assessment was determined on the basis of the sample and the standard peak area. Vitamin C content is expressed in milligrams per $100 \mathrm{~g}$ FW.

Determination of total anthocyanins. The $\mathrm{pH}$ differential method was used to determine the anthocyanins. After 1 hour, extraction of $5 \mathrm{~g}$ of the flowers in $25 \mathrm{~mL} \mathrm{35 \%}$ hydrochloric acid was conducted and the sample was filtered. A total of $0.5 \mathrm{~mL}$ filtrate was transferred into six test tubes. Into first three tubes, a 2.5-mL 0.025$\mathrm{mol} \cdot \mathrm{L}^{-1}$ solution of potassium chloride with a $\mathrm{pH}$ of 1.0 was transferred. To the remaining three tubes, a $2.5-\mathrm{mL}$ 0.4-mol. $\mathrm{L}^{-1}$ solution of sodium acetate with a $\mathrm{pH} 4.5$ was transferred. Samples were then measured using a Specord 50 Plus spectrophotometer at wavelengths of 510 and $700 \mathrm{~nm}$. The results are expressed in milligrams of anthocyanins per $100 \mathrm{~g} \mathrm{FW}$.

Determination of total carotenoids. Spectrophotometric determination of photosynthetically active pigments (carotenoids) was carried out using a Specord 50 Plus spectrophotometer at $440 \mathrm{~nm}$ according to Holm (1954). Prior to measuring, the pigments were extracted from the fine dust of dried flowers with acetone. The concentration of carotenoids is expressed in milligrams per $100 \mathrm{~g} \mathrm{FW}$.

Statistical analyses. The established data were processed using Microsoft Excel and Statistica 12 software (TIBCO Software Inc., Palo Alto, CA). A single-factor analysis of variance (level of significance, $P \leq 0.05$ ) was used for statistical processing, and Tukey's honestly significant difference test was used subsequently to assess the statistical significance of differences between individual apricot cultivar flowers. A correlation matrix between total phenolic content and antioxidant capacity was established.

\section{Results}

The average content of vitamin $\mathrm{C}$ reached $38.24 \mathrm{mg} \cdot 100 \mathrm{~g}^{-1} \mathrm{FW}$ in the studied cultivars. 'Blenheim' (47.35 mg. $100 \mathrm{~g}^{-1} \mathrm{FW}$ ) had flowers with the greatest vitamin $\mathrm{C}$ content, followed by the pink flowers of 'Marena' $\left(45.83 \mathrm{mg} \cdot 100 \mathrm{~g} \mathrm{~g}^{-1}\right.$ FW) and the white flowers of 'Vestar' (44.80 $\mathrm{mg} \cdot 100 \mathrm{~g}^{-1} \mathrm{FW}$ ) (Table 1). The lowest values in the assessed cultivars were measured in the white flowering cultivar Goldrich (24.97 mg. $100 \mathrm{~g} \mathrm{~g}^{-1}$ FW) and in the light-pink flowering cultivar Chuang Zhi Hong (29.77 mg. $100 \mathrm{~g}^{-1} \mathrm{FW}$ ). The resulting vitamin $\mathrm{C}$ values are very similar. In some cases, they differ by decimal values. Differences in the established values are highly conclusive statistically.

The greatest flavonoid values were measured in the white-flowered cultivar Stella (538.11 mg CE/100 g FW) and in the pinkflowered cultivar Marena (523.77 mg CE/100 g FW) (Table 1). The lowest values were found in white flowering cultivars Bobcot, Goldrich, Orangered, and Stark Early Orange (198.76, 230.69, 252.83, and $258.17 \mathrm{mg} \mathrm{CE} /$ 100 g FW, respectively). The average value in the tested collection was $380.37 \mathrm{mg} \mathrm{CE} /$ $100 \mathrm{~g}$ FW. Differences between cultivars were confirmed as highly conclusive statistically. 


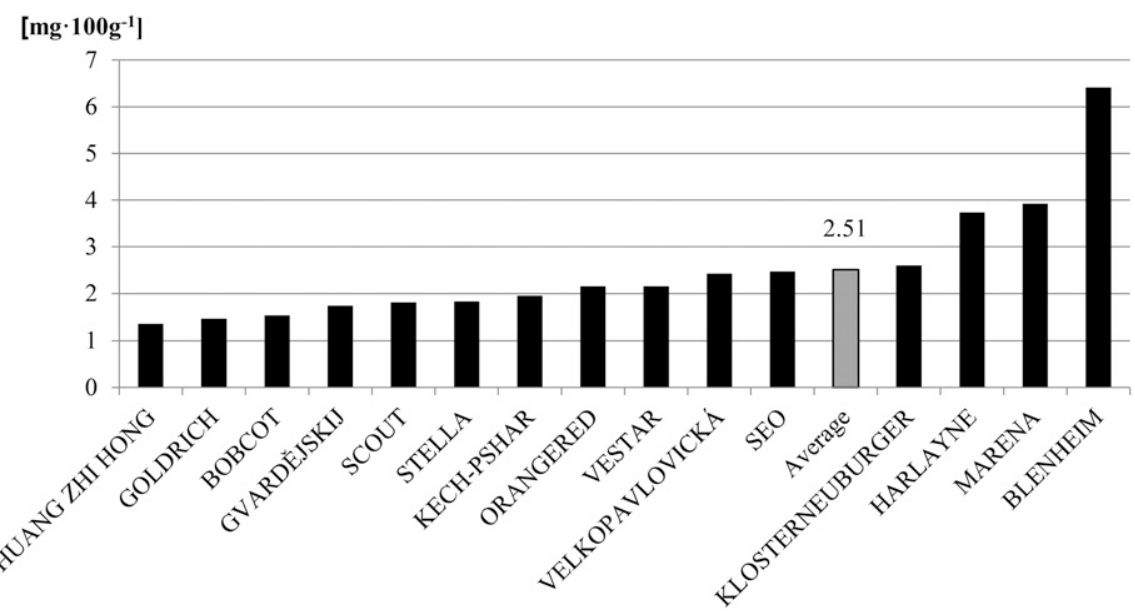

Fig. 2. Average content of carotenoids in apricot flowers.

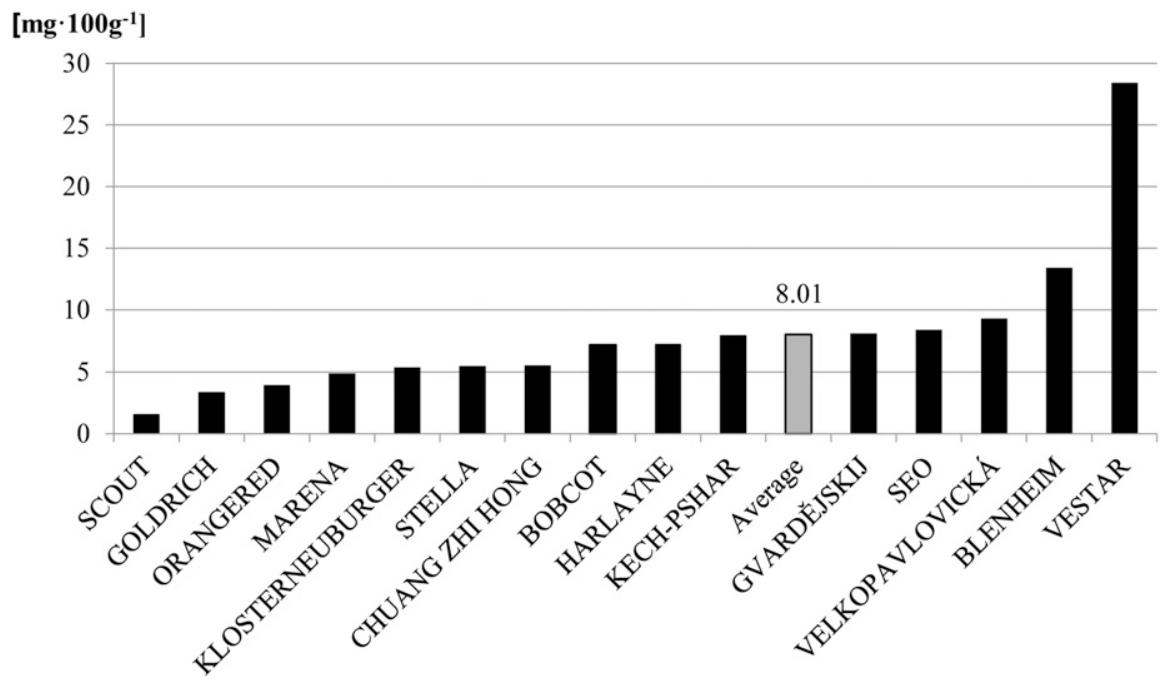

Fig. 3. Average content of anthocyanins in apricot flowers.

The greatest values in total phenolic content were found in the white flowers of 'Stella' (768.45 mg GAE/100 g FW) and 'Gvardějskij' (712.74 mg GAE/100 g FW), and in the pink flowers of 'Marena' (697.07 mg GAE/100 g FW) (Table 1). On the contrary, the lowest total phenolic content was found in the white flowers of 'Bobcot' (404.08 mg GAE/100 g FW), 'Goldrich' (430.82 mg GAE/100 g FW), and 'Orangered' (513.43 mg GAE/100 g FW). In the studied collection of cultivars, the total phenolic content ranged from 404.08 to $768.45 \mathrm{mg}$ GAE/100 g FW. Differences in the established values are highly conclusive statistically.

The average value of antioxidant activity in apricot flowers was $695.32 \mathrm{mg} \mathrm{TE} /$ $100 \mathrm{~g} \mathrm{FW}$. The highest values were found in the cultivar Stella (1026.18 mg TE/100 g FW) (Table 1). High antioxidant capacity values were also found in the light-pink flowers of 'Kech-pshar' (865.87 mg TE/ $100 \mathrm{~g} \mathrm{FW})$, the white flowers of 'Blenheim' (861.73 $\mathrm{mg} \mathrm{TE} / 100 \mathrm{~g} \mathrm{FW}$ ), and in the flowers of 'Gvardějskij' (850.68 mg TE/ $100 \mathrm{~g} \mathrm{FW})$. The lowest total antioxidant capacity was measured in the white flowers of 'Bobcot', 'Goldrich', and 'Stark Early Orange' (414.66, 442.70, and $521.19 \mathrm{mg}$ $\mathrm{TE} / 100 \mathrm{~g} \mathrm{FW}$, respectively). Differences in the established values are highly conclusive statistically.

The average content of carotenoids in the studied collections reached 2.51 $\mathrm{mg} \cdot 100 \mathrm{~g}^{-1} \mathrm{FW}$ (Fig. 2). The greatest content of carotenoids was measured in the white flowers of 'Blenheim' and 'Harlayne' (6.41 and $3.74 \mathrm{mg} \cdot 100 \mathrm{~g}^{-1} \mathrm{FW}$ ), and in the pink flowers of 'Marena' (3.92 mg.100 $\mathrm{g}^{-1}$ FW) (Table 1). The lowest values were found in the pink flowers of 'Chuang Zhi Hong' and 'Scout' (1.36 and $1.81 \mathrm{mg} \cdot 100 \mathrm{~g}^{-1}$ FW), and in the white flowers of 'Bobcot' (1.53 mg.100 g $\mathrm{g}^{-1} \mathrm{FW}$ ). Differences between cultivars were confirmed as highly conclusive statistically.

In the studied collection of cultivars, the average value of anthocyanins was 8.01 mg. $100 \mathrm{~g}^{-1}$ FW (Fig. 3). The analyzed samples with the greatest anthocyanin content were from 'Vestar' (28.41 mg. $\left.100 \mathrm{~g}^{-1} \mathrm{FW}\right)$, 'Blenheim' (13.40 mg.100 g $\mathrm{g}^{-1} \mathrm{FW}$ ), and 'Velkopavlovická' (9.31 mg.100 $\mathrm{g}^{-1} \mathrm{FW}$ ) (Table 1). The lowest values were measured in 'Scout' ( $\left.1.60 \mathrm{mg} \cdot 100 \mathrm{~g}^{-1} \mathrm{FW}\right)$, 'Goldrich' (3.38 mg. $\left.100 \mathrm{~g}^{-1} \mathrm{FW}\right)$, and 'Orangered' (3.95 $\left.\mathrm{mg} \cdot 100 \mathrm{~g}^{-1} \mathrm{FW}\right)$. Differences between cultivars were confirmed as highly conclusive statistically.

The greatest amygdalin content was measured in the pink flowers of 'Chuang Zhi Hong' (419.78 mg. $100 \mathrm{~g}^{-1} \mathrm{FW}$ ) and in the white flowers of 'Gvardějskij', 'Stark Early Orange', and 'Harlayne' (342.12, 322.51, and $315.55 \mathrm{mg} \cdot 100 \mathrm{~g}^{-1} \mathrm{FW}$, respectively) (Table 1). The lowest values were found in the white flowers of 'Bobcot' and 'Orangered' (110.81 and $137.00 \mathrm{mg} \cdot 100 \mathrm{~g}^{-1} \mathrm{FW}$ ), and in the light-pink flowers of 'Kech-pshar' (136.24 $\mathrm{mg} \cdot 100 \mathrm{~g}^{-1} \mathrm{FW}$ ). The average value of amygdalin in the tested collection was $227.29 \mathrm{mg} \cdot 100 \mathrm{~g}^{-1}$ FW (Fig. 4). Differences between cultivars were confirmed as highly conclusive statistically.

\section{Discussion}

The vitamin C content in flowers of selected apricot cultivars ranged from 24.97 to $47.35 \mathrm{mg} \cdot 100 \mathrm{~g}^{-1} \mathrm{FW}$. These values are similar to the vitamin $\mathrm{C}$ content in peeled citrus fruit, in which 47.9, 47.7, and 35.1 $\mathrm{mg} \cdot 100 \mathrm{~g}^{-1} \mathrm{FW}$ were measured in lemon, orange, and grapefruit, respectively (Akbulut et al., 2009; Kaack and Austed, 1998). The average vitamin $\mathrm{C}$ content in apricot fruit can range from $\approx 6$ to $20 \mathrm{mg} \cdot 100 \mathrm{~g} \mathrm{~g}^{-1} \mathrm{FW}$ (Gecer et al., 2020; Munzuroglu et al., 2003), which is about two to six times less than the average vitamin $\mathrm{C}$ content in flowers $(38.25 \mathrm{mg} \cdot 100$ $\mathrm{g}^{-1} \mathrm{FW}$ ).

The average content of flavonoids in the tested collection was $380.37 \mathrm{mg}$ CE/100 g $\mathrm{FW}$, which is about one magnitude greater than the content of flavonoids in apricot fruit (16.87-41.42 mg CE/100 g FW) and its dried kernels (17.33-23.56 mg CE/100 g of dry weight) (Juhaimi et al., 2018; Kafkaletou et al., 2019). A comparable flavonoid content to apricot flowers includes the flowers of the elderberry (Sambucus nigra L.) (321.92 mg CE/100 g FW) (Muchová, 2017), whereas a slightly greater content was measured in the leaves of hawthorn (Crataegus monogyna Jacq.) (407.8 mg CE/100 g FW) (Yoo et al., 2008).

In the flowers of the studied apricot cultivars, the total phenolic content ranged from 404.08 to $768.45 \mathrm{mg} \mathrm{GAE} / 100 \mathrm{~g} \mathrm{FW}$. These values are comparable to the values in fruit of common fruit species such as plums (348495 mg GAE/100 g FW) (Rop et al., 2009), blueberries (300-489 mg GAE/100 g FW) (You et al., 2011), and blackcurrants (533 mg GAE/100 g FW) (Lugasi et al., 2011). Despite a high variation in total phenolic content in apricot fruit, from 58.4 to $309.5 \mathrm{mg} \mathrm{GAE} /$ 100 g FW (Rapisarda et al., 1999), 30.3 to $742.2 \mathrm{mg} \mathrm{GAE} / 100 \mathrm{~g} \mathrm{FW}$ (Drogoudi et al., 2008), and 326 to $1600 \mathrm{mg} \cdot 100 \mathrm{~g}^{-1} \mathrm{FW}$ (Ruiz 
$\left[\mathrm{mg} \cdot 100 \mathrm{~g}^{-1}\right]$

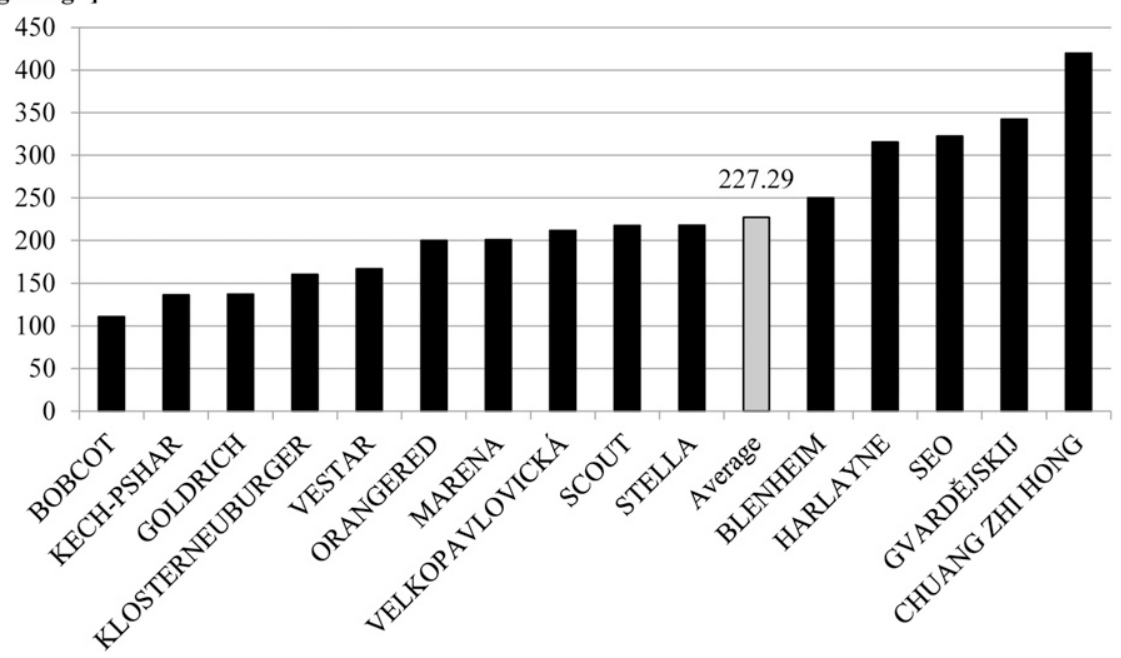

Fig. 4. Average content of amygdalin in apricot flowers.
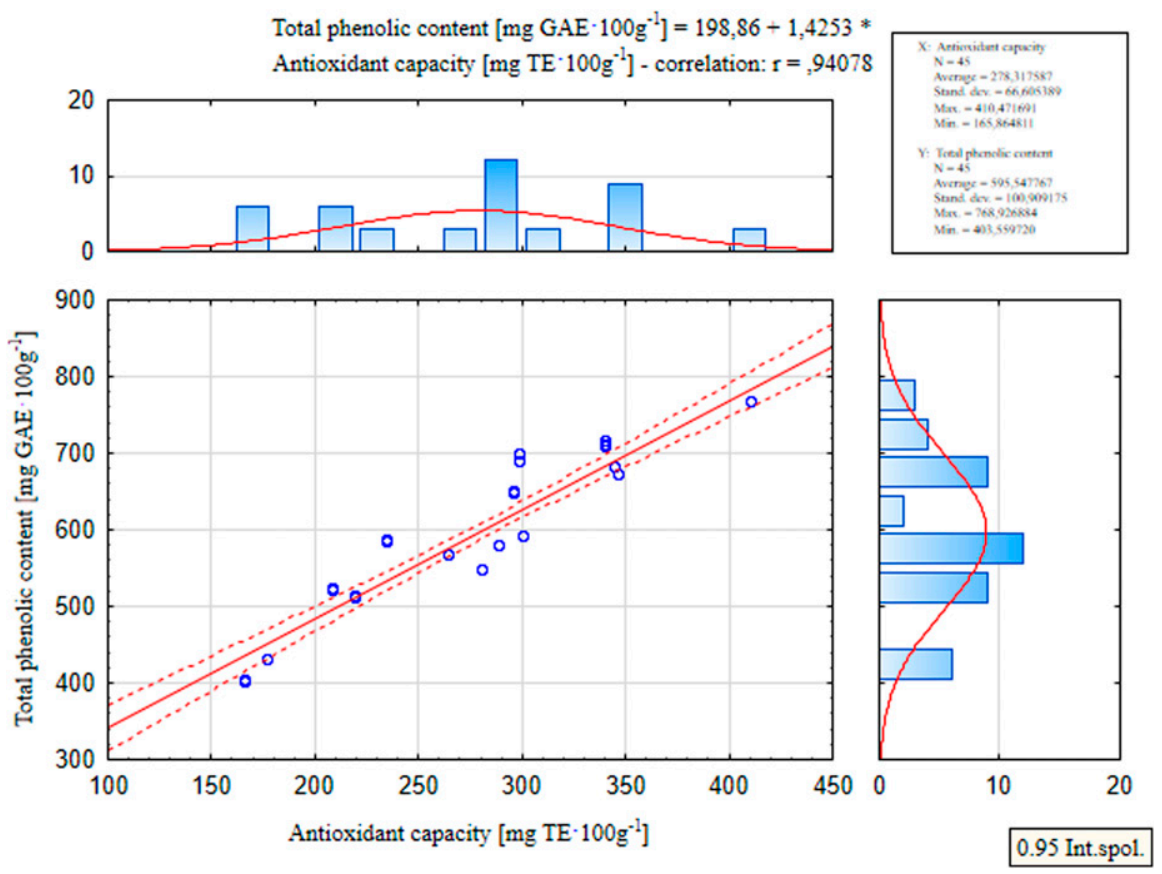

Fig. 5. The correlation coefficient between antioxidant capacity and total phenolic content. GAE, gallic acid equivalent; TE, Trolox equivalent.

et al., 2006), the apricot flowers studied have a similar total phenolic content to their fruit.

The value of antioxidant capacity is closely linked to the total phenolic content, which was confirmed in our experiment. The correlation coefficient between antioxidant capacity and total phenolic content is $r=$ 0.94078 (Fig. 5). Antioxidant capacity values of apricot flowers ranged from 414.66 to $1026.18 \mathrm{mg}$ TE/100 g FW. When compared with other flowers, a lower antioxidant capacity was measured in flowers of monks cress (Tropaeolum majus L.) (238 mg TE/ $100 \mathrm{~g} \mathrm{FW}$ ), which is used as a medicinal plant in the human diet (Navarro-González et al., 2015). Greater values were measured in the flowers of elderberry (Sambucus nigra L.)
(1499.74 mg TE/100 g FW) (Muchová, 2017). By about a magnitude lower, values of antioxidant capacity have been measured in the fruit of apples $(40.05 \mathrm{mg}$ TE/100 g $\mathrm{FW}$ ), peaches (30.54 $\mathrm{mg} \mathrm{TE} / 100 \mathrm{~g} \mathrm{FW})$, and apricots (34.79 mg TE/100 g FW) (Scalzo et al., 2005).

The average content of carotenoids in the flowers of the studied cultivars was 2.51 $\mathrm{mg} \cdot 100 \mathrm{~g}^{-1} \mathrm{FW}$, which is the lower bound of the carotenoid content in its fruit (1.50 $16.50 \mathrm{mg} \cdot 100 \mathrm{~g}^{-1} \mathrm{FW}$ ), which are well known for their high carotenoid content (Ruiz et al., 2006). In the fruit of other species, carotenoid contents, e.g., 0.20 to $1.6 \mathrm{mg} \cdot 100 \mathrm{~g}^{-1} \mathrm{FW}$ in kaki (Diospyros kaki L.) (Zhou et al., 2011) or 0.01 to $0.21 \mathrm{mg} \cdot 100 \mathrm{~g}^{-1} \mathrm{FW}$ in peaches (Gil et al., 2002), is lower than or similar to the apricot flowers.

The average content of anthocyanins in apricot flowers was $8.01 \mathrm{mg} \cdot 100 \mathrm{~g}^{-1} \mathrm{FW}$, which is similar to the anthocyanin content in their fruit, which may vary from 0.57 to 12.18 mg. $100 \mathrm{~g}^{-1}$ FW (Huang et al., 2019). Nevertheless, the apricot flowers and fruit are not considered to be rich sources of anthocyanin among other fruit species.

The amygdalin content in the flowers of selected apricot cultivars ranged from 110.81 to $419.78 \mathrm{mg} \cdot 100 \mathrm{~g}^{-1} \mathrm{FW}$. These values are much lower compared with the bitter $\left(5500-5560 \mathrm{mg} \cdot 100 \mathrm{~g}^{-1}\right)$ but also sweet (600-1580 mg.100 $\left.\mathrm{g}^{-1}\right)$ apricot kernels (Fermenia et al., 1995; Gómez et al., 1998; Yildirim and Askin, 2010), showing that the consumption of apricot flowers poses a much lower risk of poisoning from amygdalin compared with the apricot seeds. The amygdalin content in apricot flowers is very similar to that of zucchini $(210 \mathrm{mg} \cdot 100$ $\left.\mathrm{g}^{-1}\right)$ and watermelon $\left(120 \mathrm{mg} \cdot 100 \mathrm{~g}^{-1}\right)$ seeds (Bolarinwa et al., 2014), which are consumed together with their flesh without a risk.

Our study provides data about the content of biologically active substances such as vitamin $\mathrm{C}$, total phenolic content, flavonoids, carotenoids, anthocyanins, amygdalin, and antioxidant capacity in apricot flowers. When compared with the literature, apricot flowers showed a greater content of vitamin $\mathrm{C}$, flavonoids, and antioxidant capacity than their fruit. Comparable contents were measured for total phenolic content and anthocyanins, and lower amounts were measured for carotenoids in flowers compared with fruit. Moreover, a lower amount of amygdalin was measured in flowers than in seeds. Apricot flowers have greater contents of these biologically active substances than most fruit species or vegetables. Their high nutritional value, antioxidant capacity, and attractive appearance predetermine apricot flowers as a promising type of food for wider use in human nutrition. These results may contribute to the popularization of apricot flowers as a new and prospective source for the food industry and gastronomy, and a promising subject of human nutrition. However, they need to assume their correct place on the market, which will take some time to develop in society.

\section{Literature Cited}

Akbulut, M., S. Ercisli, and M. Tosun. 2009. Physico-chemical characteristics of some wild grown European elderberry (Sambucus nigra L.) genotypes. Pharmacogn. Mag. 5:320-323.

Bolarinwa, I.F., C. Orfila, and M.R.A. Morgan. 2014. Amygdalin content of seeds, kernels and food products commercially available in the UK. Food Chem. 152:133-139.

Donald, G.B. 2009. Cyanogenic foods (cassava, fruit kernels, and cycad seeds). Med. Toxicol. Nat. Substances 55:336-352.

Drogoudi, P.D., S. Vemmos, G. Pantelidis, E. Petri, C. Tzoutzoukou, and I. Karayiannis. 2008. 
Physical characters and antioxidant, sugar, and mineral nutrient contents in fruit from 29 apricot (Prunus armeniaca L.) cultivars and hybrids. J. Agr. Food Chem. 56:10754-10760.

Fermenia, A., C. Rossello, A. Mulet, and J. Canellas. 1995. Chemical composition of bitter and sweet apricot kernels. J. Agr. Food Chem. 43:356-361

Friedman, H., O. Agami, Y. Vinokur, S. Droby, L. Cohen, G. Refaeli, N. Resnick, and N. Umiel. 2010. Characterization of yield, sensitivity to Botrytis cinerea and antioxidant content of several rose species suitable for edible flowers. Scientia Hort. 123:395-401.

Gecer, M.K., T. Kan, M. Gundogdu, S. Ercisli, G. Ilhan, and H.I. Sagbas. 2020. Physicochemical characteristics of wild and cultivated apricots (Prunus armeniaca L.) from Aras Valley in Turkey. Genet. Resources Crop Evol. 67:935945.

Gil, M.I., F.A. Tomás-Barberán, B. Hess-Pierce, and A.A. Kader. 2002. Antioxidant capacities, phenolic compounds, carotenoids, and vitamin $\mathrm{C}$ contents of nectarine, peach, and plum cultivars from California. J. Agr. Food Chem. 50:4976-4982.

Gómez, E., L. Burgos, C. Soriano, and J. Marín. 1998. Amygdalin content in the seeds of several apricot cultivars. J. Agr. Food Chem. 77:184-186.

Güney, M., S. Kafkas, A. Koc, S. Aras, H. Keleş, and H. Karci. 2019. Characterization of quince (Cydonia oblonga Mill.) accessions by simple sequence repeat markers. Turkish J. Agr. For. 43:69-79

He, J., T. Yin, Y. Chen, L. Cai, Z. Tai, Z. Li, C. Liu, Y. Wang, and Z. Ding. 2015. Phenolic compounds and antioxidant activities of edible flowers of Pyrus pashia. J. Funct. Foods 17:371-379.

Holm, G. 1954. Chlorophyll mutations in barley. Acta Agr. Scand. 4:457-471.

Huang, Z., Q. Wang, L. Xia, J. Hui, J. Li, Y. Feng, and Y. Chen. 2019. Preliminarily exploring of the association between sugars and anthocyanin accumulation in apricot fruit during ripening. Scientia Hort. 248:112-117.

Juhaimi, F.A., M.M. Özcan, K. Ghafoor, and E.E. Babiker. 2018. The effect of microwave roasting on bioactive compounds, antioxidant activity and fatty acid composition of apricot kernel and oils. Food Chem. 243:414-419.

Kaack, K. and T. Austed. 1998. Interaction of vitamin $\mathrm{C}$ and flavonoids in elderberry (Sambucus nigra L.) during juice processing. Plant Foods Hum. Nutr. 52:187-198.

Kafkaletou, M., I. Kalantzis, A. Karantzi, M.V. Christopoulos, and E. Tsantili. 2019. Phytochemical characterization in traditional and modern apricot (Prunus armeniaca L.) cultivars: Nutritional value and its relation to origin. Scientia Hort. 253:195-202.
Kelley, K.M., B.K. Behe, J.A. Biernbaum, and K.L. Poff. 2001. Consumer and professional chef perceptions of three edible species. HortScience 36:162-166.

Kelley, K.M., B.K. Behe, J.A. Biernbaum, and K.L. Poff. 2002. Combinations of colours and species of containerized edible flowers: Effect on consumer preferences. HortScience 37:218 221.

Lu, B., M. Li, and R. Yin. 2015. Phytochemical content, health benefits, and toxicology of common edible flowers: A review (20002015). Crit. Rev. Food Sci. Nutr. 56:130-148.

Lugasi, A., J. Hovari, G. Kadar, and S. Denes. 2011. Phenolics in raspberry, blackberry and currant cultivars grown in Hungary. Acta Aliment. 40:52-64.

Mato, M., T. Onazaki, Y. Ozeki, D. Higeta, Y. Itoh, Y. Yoshimoto, H. Ikeda, H. Yoshida, and M. Shibata. 2000. Flavonoid biosynthesis in white flowered sim carnations (Dianthus caryophyllus). Scientia Hort. 84:333-347.

Mlček, J. and O. Rop. 2011. Fresh edible flowers of ornamental plants: A new source of nutraceutical foods. Trends Food Sci. Technol. 22:561569.

Muchová, T. 2017. Využití jedlých květů, léčivých a kořeninových rostlin pro potreby gastronomie. Mendel University, Lednice, thesis. (in Czech).

Munzuroglu, O., F. Karatas, and H. Geckil. 2003. The vitamin and selenium contents of apricot fruit of different varieties cultivated in differen geographical regions. Food Chem. 83:205212.

Navarro-González, I., R. González-Barrio, V. García-Valverde, A.B. Bautista-Ortín, and M.J. Periago. 2015. Nutritional composition and antioxidant capacity in edible flowers: Characterisation of phenolic compounds by HPLC-DAD-ESI/MSn. Intl. J. Mol. Sci. 16:805-822.

Pires, T.C., L. Barros, C. Santos-Buelga, and I.C. Ferreira. 2019. Edible flowers: Emerging components in the diet. Trends Food Sci. Technol. 93:244-258

Rapisarda, P., A. Tomaino, R. Cascio, F. Bonina, A. Pasquale, and A. Saija. 1999. Antioxidant effectiveness as influenced by phenolic content of fresh orange juices. J. Agr. Food Chem. 47:4718-4723.

Roberts, M.J. 2000. Edible \& medicinal flowers. 1st ed. New Africa Books, Claremont, South Africa.

Rop, O., J. Mlček, T. Jurikova, J. Neugebauerova, and J. Vabkova. 2012. Edible flowers: A new promising source of mineral elements in human nutrition. Molecules 17:6672-6683.

Rop, O., T. Juríková, J. Mlček, D. Kramářová, and Z. Sengee. 2009. Antioxidant activity and selected nutritional values of plums (Prunus domestica L.) typical of the White
Carpathian Mountains. Scientia Hort. 122:545-549.

Ruiz, D., J. Egea, M.I. Gil, and F.A. TomasBarberan. 2006. Phytonutrient content in new apricot (Prunus armeniaca L.) varieties. Acta Hort. 717:363-368.

Sawant, L., B. Prabhakar, and N. Pandita. 2010. Quantitative HPLC analysis of ascorbic acid and gallic acid in Phyllanthus emblica. J. Anal. Bioanal. Technol. 1:111.

Scalzo, J., A. Politi, N. Pellegrini, B. Mezzetti, and M. Battino. 2005. Plant genotype affects total antioxidant capacity and phenolic contents in fruit. Nutrition 21:207-213.

Senica, M., F. Stampar, and M.M. Petkovsek. 2019. Different extraction processes affect the metabolites in blue honeysuckle (Lonicera caerulea L. subsp. edulis) food products. Turkish J. Agr. For 43:576-585.

World Health Organization. 2012. Cyanogenic glycosides. WHO food additives series 30. 16 Feb. 2020. <http://www.inchem.org/documents/ jecfa/jecmono/v30je18.htm $>$.

Yang, S.L. and T.W. Walters. 1992. Ethnobotany and the economic role of the Cucurbitaceae in China. Econ. Bot. 46:349-367.

Yildirim, F.A. and M.A. Askin. 2010. Variability of amygdalin content in seeds of sweet and bitter apricot cultivars in Turkey. African J. Biotechnol 9:6522-6524.

Yoo, K.M., C.H. Lee, H. Lee, B. Moon, and C.Y. Lee. 2008. Relative antioxidant and cytoprotective activities of common herbs. Food Chem. 106:929-936.

You, Q., B.W. Wang, F. Chen, Z.L. Huang, X. Wang, and P.G. Luo. 2011. Comparison of anthocyanins and phenolics in organically and conventionally grown blueberries in selected cultivars. Food Chem. 125:201208 .

Zbíral, J. 2005. Analýza rostlinného materiálu: Jednotné pracovní postupy. Vyd. 2, rozš. a přeprac. Ústřední Kontrolní a Zkušební Ústav Zemědělský, Brno. (in Czech).

Zhou, C., D. Zhao, Y. Sheng, J. Tao, and Y. Yang. 2011. Carotenoids in fruits of different persimmon cultivars. Molecules 16:624636.

Zia-Ul-Haq, M., S. Ahmad, S.A. Bukhari, R. Amarowicz, S. Ercisli, and H.Z. Jaafar. 2014. Compositional studies and biological activities of some mash bean (Vigna mungo (L.) Hepper) cultivars commonly consumed in Pakistan. Biol. Res. 47:23.

Zloch, Z., J. Čelakovský, and A. Aujezdská. 2004. Stanovení obsahu polyfenolů a celkové antioxidační kapacity $\mathrm{v}$ potravinách rostlinného původu. Závěrečná zpráva o plnění výzkumného projektu podpořeného finančně Nadačním fondem Institutu Danone. Ústav Hygieny Lékařské Fakulty UK Plzeň, Plzeñ. (in Czech). 